\title{
Rates of Sea Level Changes-A Clarifying Note
}

\author{
Nils-Axel Mörner \\ Paleogeophysics \& Geodynamics, Stockholm, Sweden \\ Email: morner@pog.nu
}

How to cite this paper: Mörner, N.-A. (2016)

Rates of Sea Level Changes-A Clarifying

Note. International Journal of Geosciences, 7, 1318-1322.

http://dx.doi.org/10.4236/ijg.2016.711096

Received: October 13, 2016

Accepted: November 25, 2016

Published: November 28, 2016

Copyright (๑) 2016 by author and Scientific Research Publishing Inc. This work is licensed under the Creative Commons Attribution International License (CC BY 4.0).

http://creativecommons.org/licenses/by/4.0/

\begin{abstract}
The values of present to future rates in sea level changes vary in an almost chaotic way. In view of the urgent need to handle this question in a constructive way, we must anchor the issue in observational facts, physical laws and long-term scientific experience. Doing so, we can put a solid ultimate frame of any possible rise in sea level in the next centuries: viz. $10.0 \mathrm{~mm} / \mathrm{yr}$ or $1.0 \mathrm{~m}$ per century. If this is the ultimate possible rate, the expected rate in the 21 st century must be far less. The author's proposition is $+5 \mathrm{~cm} \pm 15 \mathrm{~cm}$ by year 2100 .
\end{abstract}

\section{Keywords}

Sea Level Changes, Ultimate Rise, GISP2 Temperature, 2100 Prediction

\section{Introduction}

In newspapers, television and numerous blogs, there are no limits of how fast and how much sea level is said to rise. Even a rise in the order of 2 to $5 \mathrm{~m}$ by year 2100 has been claimed. We may ask what such figures really imply with respect to proper scientific knowledge, facts recorded in nature and physical laws. The answer is simple; such an enormous rate of sea level changes and any amount exceeding $1 \mathrm{~m}$ in a century, represent nothing but unscientific nonsense that does not concur with observational facts, accumulated knowledge through centuries and physical laws. I have addressed this question before [1] [2] [3]. In media and anthropogenic global warming literature there seems to be a desperate demagogic ambition to present maximum horror scenarios, however.

In the present paper I will provide some short comments and updates, indicating that the maximum rate of sea level rise can be firmly set at $10.0 \pm 1.0 \mathrm{~mm} /$ year or $1.0 \mathrm{~m}$ per century. The paper can be seen as a direct addition to my previous paper in this journal [3]. 


\section{Maximum Rates of Sea Level Rise}

I have shown [1] that the ultimate rate of sea level changes in present time can be set at $1.0 \mathrm{~mm} / \mathrm{yr}$ or $1.0 \mathrm{~m}$ in a century. The reason for this is that the rise of sea level rise some 10,000 - 11,000 years ago did not exceed this rate, although the climate forcing was exceptionally strong and the rate of glacier retreat was very rapid (in the order of $200-300 \mathrm{~m}$ per year in the Stockholm region). This is perfectly true, but can now be illustrated in a still more expressive way. The Greenland GISP2 temperature record [4] [5] record the exceptionally large change in temperature that occurred at the end of the Younger Dryas and Early Holocene (Figure 1), and still- and this is the amazing thingsea level did not rise more than by about $10 \mathrm{~mm} / \mathrm{yr}$ (i.e. $1.0 \mathrm{~m}$ per century) as recorded with high precision in Northwest Europe and tested globally [6] [7].

At 11,000 BP we had enormous amounts of ice still left in the huge continental ice caps of the Last Ice Age. In Canada, the ice front was in St. Lawrence lowland, and in Scandinavia, the ice margin was at Stockholm. At the warming pulse ending the Pleistocene and starting the Holocene, ice melted at an exceptionally strong forcing. Today, there is neither ice nor climate forcing that in any way can be compared to what happened 11,000 - 10,000 BP.

The conclusion is obvious; we can never in present time have any ice melting and sea level rise as strong- and certainly not stronger-than that occurring at the Pleistocene/

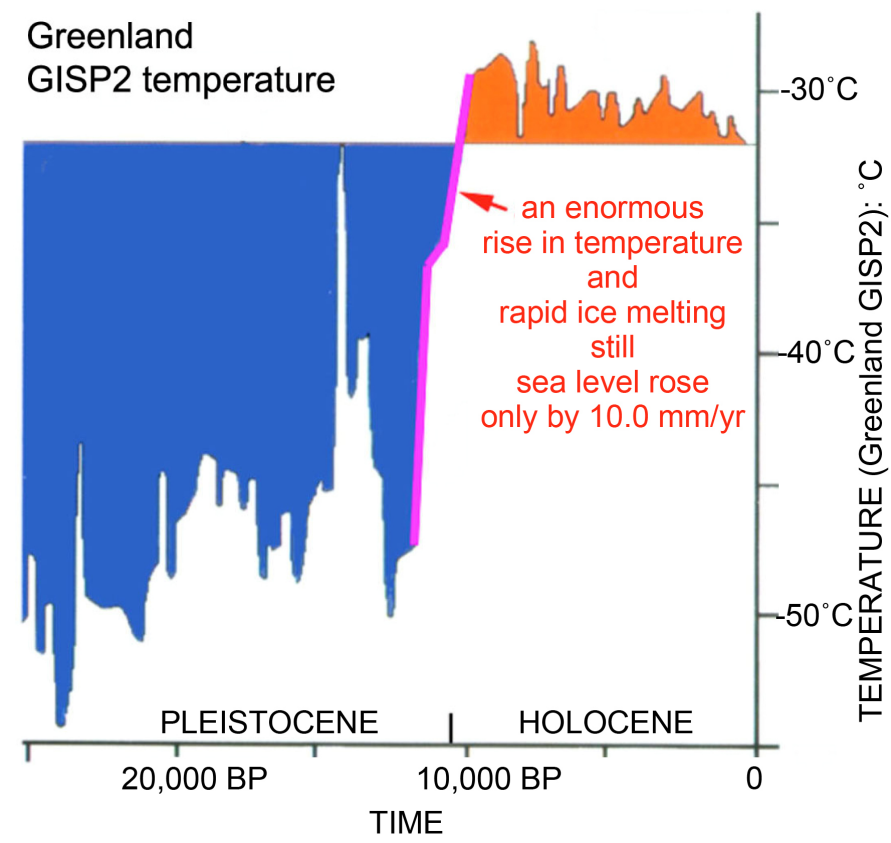

Figure 1. The Greenland GISP2 temperature record [4] [5] with an exceptionally large and rapid rise in temperature at around the Pleistocene/Holocene boundary. Although the ice recession was very strong and rapid at the same time, sea level did not rise faster than by $10.0 \mathrm{~mm} / \mathrm{yr}$ or $1.0 \mathrm{~m}$ per century [1]. This in its turn provides firm evidence that any rise in sea level today and in the near future cannot exceed that rate, rather it must be considerably less. 
Holocene transition. Therefore, a rate of sea level rise of $+10.0 \mathrm{~mm} / \mathrm{yr}$ or $1.0 \mathrm{~m}$ per century can be held as the absolutely ultimate value of any present day sea level rise [1]. Any present rise in sea level must be far below this value to be realistic in view of past records and the physical factors controlling ice melting. Therefore, we can also dismiss any claim of sea level rise exceeding $1 \mathrm{~m}$ in the next century as sheer nonsenses and unfounded demagoguery.

This is illustrated in Figure 2, where the green square represents the $\pm 1.0 \mathrm{~mm} / \mathrm{yr}$ amplitude of observed sea level changes in the last 300 years [2], the blue square marks the box within which all serious present day rate estimates have to be, if based on observational facts, accumulated knowledge and physical laws, the yellow frame of +10.0 $\pm 1.0 \mathrm{~mm} / \mathrm{yr}(1.0 \pm 0.1 \mathrm{~m} / \mathrm{cy})$ provides the ultimate frame of possible present day sea level rise discriminating between possible and impossible claims of present to future changes in sea level, and grey zone which gives the rates and amplitudes where any present to future claim of sea level rise must be classified as invalid propaganda or inferior knowledge in the science of sea level changes.

\section{Observed Sea Level Changes}

In my previous paper in this journal [3], I gave a general account of what we really observe in the field; i.e. available observational facts. I will return to this question, as it gives the base for determining where we are today in the blue and green squares of Figure 2.

This value has to be found within the zone ranging between \pm 0.0 and $+2.0 \mathrm{~mm} / \mathrm{yr}$ (i.e. yellow zone in Figure 3). We can now narrow down this window even better, as illustrated by points $1-5$ in Figure 3. The five points provide the following information.

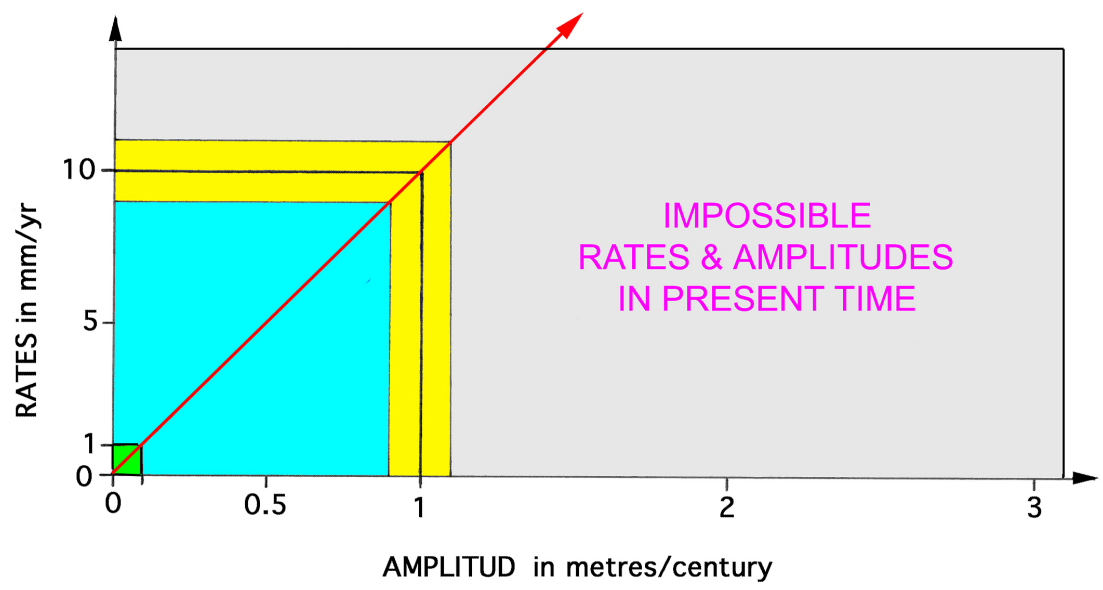

Figure 2. Rates and amplitudes of sea level changes (modified from [1]). Yellow frame $(10.0 \pm 1.0 \mathrm{~mm} / \mathrm{yr}$ or $1.0 \pm 0.1 \mathrm{~m} / \mathrm{cy})$ gives the ultimate boundary for any realistic claim of present to future sea level rise, which have to fall inside to well inside this frame. The green square gives observed variations in sea level over the last 300 years [2]. 


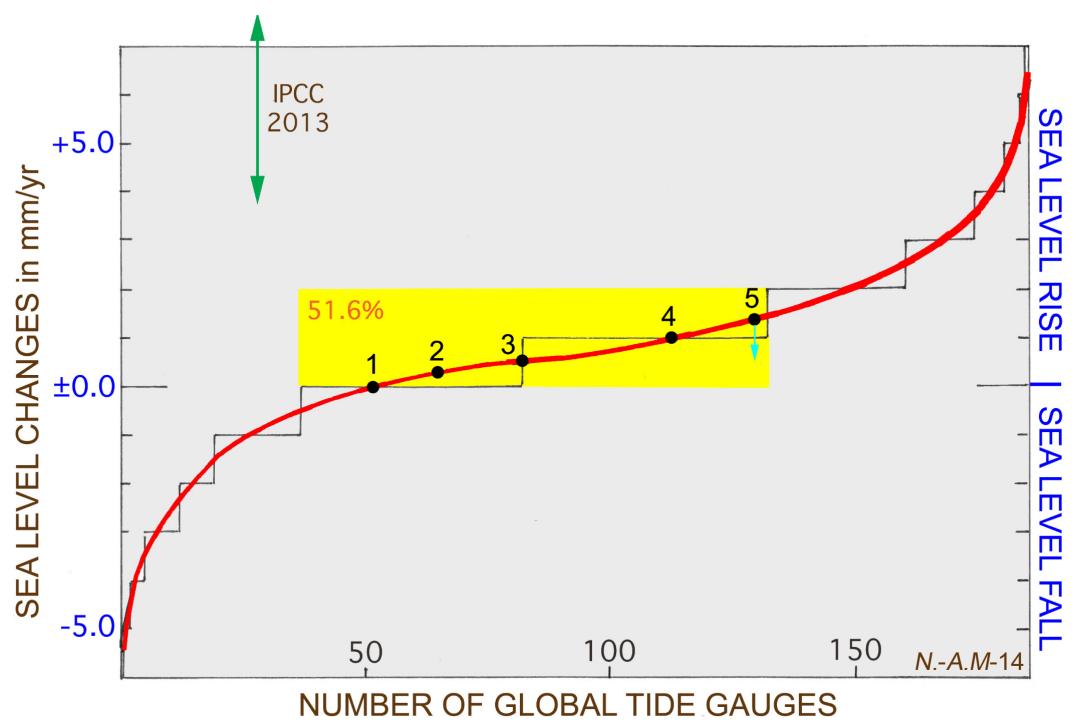

Figure 3. The new spectrum of sea level (modified from [3]). The five points, further discussed in the text, provide a congruent picture: sea level is globally varying between \pm 0.0 and $+1.0 \mathrm{~mm} / \mathrm{yr}(0.5 \pm 0.5 \mathrm{~mm} / \mathrm{yr})$. Only the estimate by the IPCC

[11] is above "hanging in the air".

- $+1.14 \mathrm{~mm} / \mathrm{yr}$, the mean of 184 tide gauge records scattered all over the globe selected by [8] for their global sea level analyses. This value is too high, however, because many sites used represent subsiding delta sites [3].

- $+1.0 \pm 0.1 \mathrm{~mm} / \mathrm{yr}$, the eustatic component the North Sea, Kattegatt and Baltic region [3] [9].

- $+0.55 \pm 0.10 \mathrm{~mm} / \mathrm{yr}$, the revised satellite altimetry values of [3].

- $+0.25 \pm 0.19 \mathrm{~mm} / \mathrm{yr}$, the mean of 170 PSMSL tide gauge stations having a length of more than 60 years [10].

- $\pm 0.0 \mathrm{~mm} / \mathrm{yr}$, the value obtained from many global test sites [1] [3] [9]; the Maldives, Bangladesh, Goa in the Indian Ocean, Tuvalu, Vanuatu, Kiribati, Majuro in the Pacific, Surinam-Guyana in NE South America, Venice in the Mediterranean.

This provides quite a congruent picture of a present global change in sea level varying between \pm 0.0 and $+1.0 \mathrm{~mm} / \mathrm{yr}$ (or $0.5 \pm 0.5 \mathrm{~mm} / \mathrm{yr}$ ), which implies that we are still within the green square of Figure 2.

\section{Conclusions}

The temperature rise, ice melting and sea level rise at the Pleistocene/Holocene transition (Figure 1) provide an excellent value of what we may consider as the ultimate possible rate of sea level rise in present to near future time. This value is $10.0 \mathrm{~mm} / \mathrm{yr}$ or $1.0 \mathrm{~m} / \mathrm{cy}$.

Any claim of faster rates can therefore be directly dismissed as unrealistic [1].

The present rate of sea level rise varies globally between \pm 0.0 and $+1.0 \mathrm{~mm} / \mathrm{yr}$; i.e. zero to $10 \mathrm{~cm}$ in a century. This value fits very well with the author's proposal of a sea level rise by year 2100 of $+5 \mathrm{~cm} \pm 15 \mathrm{~cm}$ [3] [9]. 


\section{References}

[1] Mörner, N.-A. (2011) Setting the Frames of Expected Future Sea Level Changes by Exploring Past Geological Sea Level Records. In: Easterbrook, D.J., Ed., Evidence-Based Climate Science, Chapter 6, Elsevier, Amsterdam, 185-196. https:/doi.org/10.1016/b978-0-12-385956-3.10006-3

[2] Mörner, N.-A. (2013) Sea Level Changes: Past Records and Future Expectations. Energy \& Environment, 24, 509-536. https:/doi.org/10.1260/0958-305X.24.3-4.509

[3] Mörner, N.-A. (2015) Glacial Isostasy: Regional-Not Global. International Journal of Geoseciences, 6, 577-592. https:/doi.org/10.4236/ijg.2015.66045

[4] Cuffey, K.M. and Clow, G.D. (1997) Temperature, Accumulation and Ice Sheet Elevation in Central GREENLAND through the Last Deglacial Transition. Journal of Geophysical Research, 102, 26383-26396. https:/doi.org/10.1029/96JC03981

[5] Easterbrook, D.J. (2011) Geological Evidence of Recurring Climate Cycles and Their Implications for the Cause of Global Climate Change-The Past Is the Key to the Future. In: Easterbrook, D.J., Ed., Evidence-Based Climate Science, Chapter 1, Elsevier, Amsterdam, 3-51.

[6] Mörner, N.-A. (1971) Eustatic Changes during the Last 20,000 Years and a Method of Separating the Isostatic and Eustatic Factors in an Uplifted Area. Palaeogeography, Palaeoclimatology, Palaeoecology, 9, 153-181. https:/doi.org/10.1016/0031-0182(71)90030-7

[7] Mörner, N.-A. (1980) The Northwest European "Sea-Level Laboratory" and Regional Holocene Eustasy. Palaeogeography, Palaeoclimatology, Palaeoecology, 29, 181-300.

[8] UC, University of Colorado (2013) Sea Level Research Group of University of Colorado. http://sealevel.colorado.edu/

[9] Mörner, N.-A. (2016) Sea Level Changes as Observed in Nature. In: Easterbrook, D.J., Ed., Evidence-Based Climate Science, 2nd Edition, Chapter 12, Elsevier, Amsterdam, 215-229. https:/doi.org/10.1016/b978-0-12-804588-6.00012-4

[10] Parker, A. and Ollier, C.D. (2015) Sea Level Rise for India since the Start of Tide Gauge Records. Arabian Journal of Geosciences, 8, 6483-6495. https:/doi.org/10.1007/s12517-014-1739-6

[11] IPCC (2013) Fifth Assessment Report. The Intergovernmental Panel on Climate Change.

Submit or recommend next manuscript to SCIRP and we will provide best service for you:

Accepting pre-submission inquiries through Email, Facebook, LinkedIn, Twitter, etc.

A wide selection of journals (inclusive of 9 subjects, more than 200 journals)

Providing 24-hour high-quality service

User-friendly online submission system

Fair and swift peer-review system

Efficient typesetting and proofreading procedure

Display of the result of downloads and visits, as well as the number of cited articles

Maximum dissemination of your research work

Submit your manuscript at: http://papersubmission.scirp.org/

Or contactijg@scirp.org 